\title{
Benthic variability in intertidal soft-sediments in the mesohaline part of the Schelde estuary
}

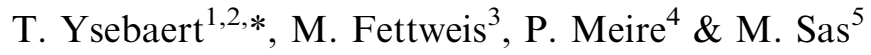 \\ ${ }^{1}$ Netherlands Institute of Ecology (NIOO-KNAW), Centre for Estuarine and Marine Ecology, Korringaweg 7, \\ 4400 AC Yerseke, The Netherlands \\ ${ }^{2}$ Institute of Nature Conservation, Kliniekstraat 25, B-1050 Brussel, Belgium \\ ${ }^{3}$ Management Unit of the North Sea Mathematical Models (MUMM), Royal Belgian Institute of Natural Science, \\ Gulledelle 100, B-1200 Brussel, Belgium \\ ${ }^{4}$ Department Biology, University of Antwerp, Universiteitsplein 1, B-2610 Wilrijk, Belgium \\ ${ }^{5}$ International Marine \& Dredging Consultants N.V., Wilrijkstraat 37-45 B4, B-2140 Antwerpen, Belgium \\ (*Author for correspondence: E-mail: t.ysebaert@nioo.knaw.nl)
}

Key words: intertidal mudflats, soft-sediments, benthic fauna, macrobenthos, microphytobenthos, mesohaline, Schelde estuary

\begin{abstract}
The benthic (zoobenthos and microphytobenthos) and physical characteristics of intertidal sediments were studied in April and September 1997 on 10 locations, differing in elevation and exposure to tidal currents, situated on three mudflats in the mesohaline part of the Schelde estuary. Sediment characteristics were spatially and temporally relatively homogeneous among the sampling locations, all characterized by a high proportion of mud. It emerged that the nature of the sediment (in terms of granulometric characterization, organic matter) did not fully explain the substantial spatial and temporal (seasonal) variability in the benthos (pigment contents and benthic fauna), but that other environmental conditions explained the observed variability. Chlorophyll $a$ and fucoxanthin contents in the top layer $(0-0.5 \mathrm{~cm})$ of the sediment were about 7 times higher in April than in September, but a large spatial variation was observed, especially in April, which was mainly attributed to a difference in elevation of the mudflats. The high pigment contents in April were accompanied by a relative low abundance of the benthic fauna. In April sub-surface deposit feeders, mainly Oligochaeta, were numerically most important in the 1000 and $500 \mu$ m fraction of the zoobenthos, and Nematodes in the $250 \mu \mathrm{m}$ fraction. The surface deposit feeders Manayunkia aestuarina and Copepoda were locally very abundant, showing a strong positive correlation with elevation and pigment contents. The critical shear stress for erosion, measured in situ with the SedErode device, varied between 0.26 and $0.43 \mathrm{~N} \mathrm{~m}^{-2}$ in April. The critical shear stress for erosion was lower in September when pigment contents were significantly lower and benthic fauna abundance was higher. In September Corophium volutator, Heteromastus filiformis, Nereis diversicolor and Macoma balthica dominated the $1000 \mu \mathrm{m}$ fraction, Oligochaeta and $C$. volutator the $500 \mu \mathrm{m}$ fraction, and Nematodes, M. aestuarina, Oligochaeta and Copepoda the $250 \mu \mathrm{m}$ fraction. It is argued that in estuarine systems with high seasonal variability in river flow rate and therefore salinity, the upper-middle estuarine fauna may switch each year between an oligohaline and a mesohaline fauna, which result in communities that seldom progress beyond early benthic-community succession. The majority of the benthic infauna was found in the upper $3 \mathrm{~cm}$ in both seasons, with surface deposit feeders (e.g. C. volutator, M. aestuarina) mainly occurring in the top $1 \mathrm{~cm}$ of the sediment, showing a strong correlation with both elevation and pigment contents and subsurface deposit feeders (e.g. H. filiformis, Oligochaeta) occurring deeper in the sediment, showing a positive correlation with the mud content of the sediment.
\end{abstract}




\section{Introduction}

Macro-tidal estuaries are often characterized by extended intertidal mud and sand flats. Despite the fact that intertidal benthic biota have to survive in a harsh and variable environment, intertidal flats are sites of intense biological activity with often a high productivity (Heip et al., 1995; Herman et al., 1999), supporting large populations of birds and forming nursery and feeding areas for coastal fisheries. Such habitats are controlled by a relatively small set of benthic key species and abiotic processes, but the interactions between the biotic and abiotic factors and their influence on sediment processes, suspended solids concentrations and resultant estuarine morphology are complex and still poorly characterized.

For the Schelde estuary, one of the larger NW-European estuaries with a complete salinity gradient, the intertidal macrobenthic communities along the estuarine salinity gradient are well described (e.g. Ysebaert et al., 1993, 1998, 2003; Ysebaert \& Herman, 2002). These studies demonstrated a clear decrease in macrobenthic species diversity and biomass from the polyhaline zone towards the meso-/oligohaline zone. Other benthic studies in the Schelde estuary focused on tidal flat dynamics in the polyhaline reaches of the estuary, and investigated population dynamics and spatial patterns of bivalves (Bouma et al., 2001a, b), food resources for macrobenthos using stable isotope techniques (Herman et al., 2000; Middelburg et al., 2000), benthic community structure and sediment processes (Herman et al., 2001), and the impact of biotic and abiotic processes on sediment dynamics (de Brouwer et al., 2000; Widdows et al., 2000; De Deckere, 2003). The latter studies showed the important role benthos might play in affecting sediment transport processes by influencing the physical stability and erodability of natural cohesive sediments (for reviews see Paterson \& Black, 1999; Widdows \& Brinsley, 2002), but differences in forcing variables highlight the need for site-specific information (Defew et al., 2002). Within the highly fluctuating meso-/ oligohaline transition zone, with its characteristic sharp physicochemical gradients and high concentrations of suspended sediment (maximum turbidity zone, Herman et al., 1999), more detailed information on the spatio-temporal variation of the benthos, and their interaction with the abiotic environment, is however lacking. In general, benthic communities of upper oligo-mesohaline regions have received little attention as compared to the lower reaches of estuaries, but a few studies showed large seasonal fluctuations in the occurrence of benthic infauna (e.g. Holland et al., 1987; Santos et al., 1996).

The aim of this study was to investigate the spatial and temporal variability in microphytobenthos biomass and benthic fauna community structure (species richness, abundance, biomass, trophic groups, vertical distribution) in relation to environmental characteristics of intertidal sediments, based on a sampling in spring and autumn of ten locations on three mudflats, differing in elevation and exposure to tidal currents, in the low salinity region of the Schelde estuary.

\section{Material and Methods}

\section{The Schelde estuary}

The Schelde estuary is situated in the NW of Belgium and the SW of The Netherlands. This macro-tidal estuary is a turbid, nutrient-rich and heterotrophic system (Heip et al., 1995). Extensive dredging activities are performed for the maintenance of shipping traffic to the harbour of Antwerpen. The study area, situated near the Dutch/Belgian border, about 55-60 km upstream of the mouth of the estuary (Fig. 1), experiences mesohaline salinity conditions $(5-18)$ most of the time. Surface water salinity was 9.5 in April 1997 and 13.4 in September 1997. Prior to sampling salinity was on average 7.2 and 10.5 during the periods January-March and June-August 1997, respectively, with minima reaching oligohaline conditions (salinity <5). Mean tidal range is $4.94 \mathrm{~m}$, ranging from $5.64 \mathrm{~m}$ during spring tide to $4.02 \mathrm{~m}$ during neap tide. The turbidity maximum is situated at about $110 \mathrm{~km}$ from the mouth during dry periods and at about $50 \mathrm{~km}$ during wet periods. Periods with high rainfall are more concentrated during winter. This explains to a major part the observed coupling of suspended mud concentration with seasons in the study area, where the 

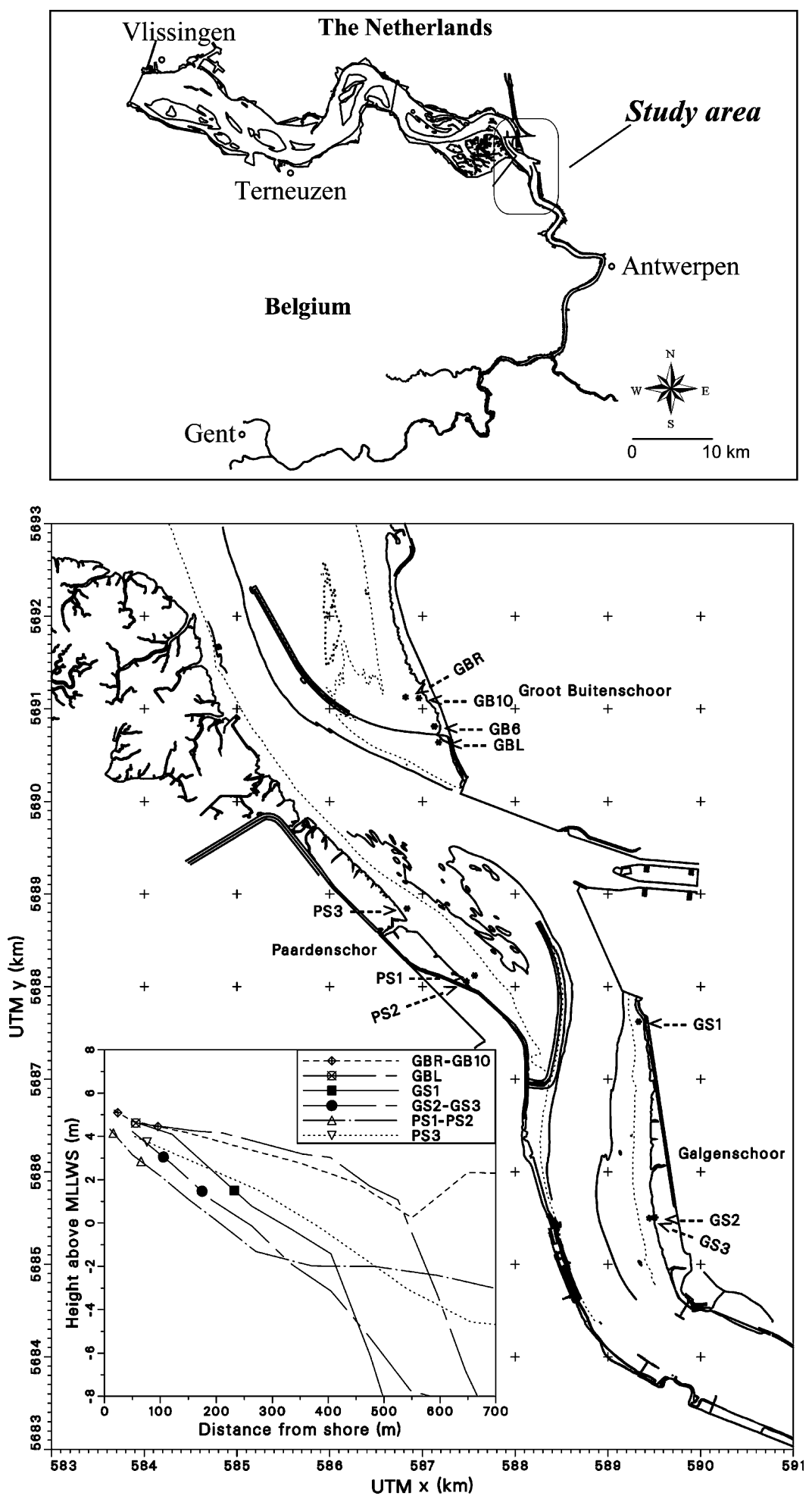

Figure 1. Map of the Schelde estuary with a detailed map of the mesohaline part showing the three mudflats (Buitenschoor (GB), Galgenschoor (GS) and Paardenschor (PS)) and the ten sampling locations. For each mudflat the slope and the height above Mean low low water spring (MLLWS, m) of each location are given. 
high suspended mud concentrations are generally occurring during winter and the low ones during summer (Fettweis et al., 1998).

\section{Description of the study sites}

The field measurements were carried out on 10 intertidal locations (Fig. 1) which were sampled in April and September 1997 under dry weather conditions. Mean temperature of the surface sediment was $14.3^{\circ} \mathrm{C}$ (range 8.6-18.0 ${ }^{\circ} \mathrm{C}$ ) in April and $21.3{ }^{\circ} \mathrm{C}\left(18.7-26.3{ }^{\circ} \mathrm{C}\right)$ in September. The locations were situated on three mudflats that differ in elevation and exposure to tidal currents (Fig. 1). The Galgenschoor mudflat (GS, three locations) has a relatively steep slope and is directly connected to the main channel. The Paardenschor mudflat (PS, three locations) has a less steep slope and is protected by a submerged dam near the navigation channel. The Buitenschoor mudflat (GB, four locations) has a shallow slope and is protected by a sandflat and a dam. The height of the sampling locations differed considerably, ranging from $+1.92 \mathrm{~m}$ to $+5.61 \mathrm{~m}$ MLLWS (Table 1, Fig. 1), resulting in a different period of flooding between approximately 9.30 and $1.40 \mathrm{~h}$ during a mean tidal cycle. A 3D hydrodynamic model (Fettweis \& Sas, 1999) showed that maximum flood currents during spring tide differ substantially in magnitude among the three mudflats: $0.7-0.9 \mathrm{~m} \mathrm{~s}^{-1}$ on Galgenschoor, 0.5-0.6 $\mathrm{m} \mathrm{s}^{-1}$ on Buitenschoor and $0.25-0.45 \mathrm{~m} \mathrm{~s}^{-1}$ on Paardenschor, respectively. Maximum ebb currents during spring tide are substantially lower on Galgenschoor $\left( \pm 0.4 \mathrm{~m} \mathrm{~s}^{-1}\right)$ and Paardenschor $\left(0.1-0.2 \mathrm{~m} \mathrm{~s}^{-1}\right)$, but have the

Table 1. Sediment characteristics of the 10 sampling locations in April and September (average per location)

\begin{tabular}{|c|c|c|c|c|c|c|c|c|}
\hline \multirow{2}{*}{$\begin{array}{l}\text { Sampling } \\
\text { location } \\
\text { Depth rang } \\
\text { (cm) }\end{array}$} & \multirow{2}{*}{ Height $\mathrm{m}$} & \multicolumn{2}{|c|}{$\mathrm{D} 50 \mu \mathrm{m}$} & \multicolumn{2}{|c|}{ Mud \% } & \multirow{2}{*}{$\begin{array}{l}\text { Org. \% } \\
- \\
0-0.5\end{array}$} & \multirow{2}{*}{$\begin{array}{l}\rho \mathrm{kg} \mathrm{m}^{-3} \\
0-0.3\end{array}$} & \multirow[t]{2}{*}{$\tau_{\mathrm{cr}} \mathrm{N} \mathrm{m}^{-2}$} \\
\hline & & $0-0.5$ & $0-10$ & $1-0.5$ & $0-10$ & & & \\
\hline \multicolumn{9}{|l|}{ April } \\
\hline GB10 & 5.55 & 43 & 63 & 62 & 50 & 9 & 1256 & $0.42(0.39-0.45)$ \\
\hline GB6 & 5.61 & 27 & 61 & 72 & 51 & 12 & 1332 & $0.26(0.25-0.26)$ \\
\hline GBL & 5.07 & 68 & 136 & 48 & 23 & 5 & 1493 & $0.33(0.27-0.37)$ \\
\hline GBR & 4.91 & 27 & 41 & 74 & 62 & 12 & 1315 & $0.43(0.42-0.43)$ \\
\hline GS1 & 1.96 & 43 & 59 & 63 & 52 & 7 & 1563 & $0.26(0.25-0.29)$ \\
\hline GS2 & 3.50 & 118 & 60 & 29 & 52 & 3 & 1811 & $0.30(0.30-0.31)$ \\
\hline GS3 & 1.92 & 31 & 34 & 72 & 66 & 10 & 1546 & $0.30(0.27-0.36)$ \\
\hline PS1 & 3.30 & 52 & 35 & 58 & 69 & 6 & 1507 & $0.35(0.29-0.38)$ \\
\hline PS2 & 4.61 & 30 & 28 & 76 & 75 & 8 & 1306 & $0.30(0.26-0.35)$ \\
\hline PS3 & 4.20 & 61 & 76 & 52 & 41 & 3 & 1642 & $0.32(0.29-0.39)$ \\
\hline \multicolumn{9}{|l|}{ September } \\
\hline GB10 & 5.55 & 37 & 48 & 71 & 59 & 5 & 1589 & $0.29(0.26-0.33)$ \\
\hline GB6 & 5.61 & 37 & 37 & 70 & 67 & 7 & 1559 & $0.27(0.26-0.28)$ \\
\hline GBL & 5.07 & 124 & 131 & 27 & 23 & 3 & 1783 & $0.29(0.27-0.30)$ \\
\hline GBR & 4.91 & 33 & 28 & 73 & 75 & 7 & 1477 & $0.25(0.22-0.27)$ \\
\hline GS1 & 1.96 & 41 & 75 & 63 & 44 & 5 & 1445 & $0.24(0.23-0.26)$ \\
\hline GS2 & 3.50 & 36 & 50 & 72 & 60 & 7 & 1402 & $0.29(0.29-0.30)$ \\
\hline GS3 & 1.92 & 45 & 34 & 62 & 68 & 7 & 1432 & $0.25(0.27-0.36)$ \\
\hline PS1 & 3.30 & 27 & 40 & 77 & 66 & 7 & 1464 & $0.23(0.22-0.25)$ \\
\hline PS2 & 4.61 & 35 & 42 & 71 & 64 & 6 & 1566 & $0.26(0.26-0.27)$ \\
\hline PS3 & 4.20 & 37 & 64 & 71 & 49 & 5 & 1531 & $0.26(0.24-0.28)$ \\
\hline
\end{tabular}

Height $=$ height of each location in $+\mathrm{m}$ MLLWS; D50 = median grain size; Mud $=$ volume $\%<63 \mu \mathrm{m}$; Org. $=$ organic content in weight $\% ; \rho=$ bulk density of the sediment; $\tau_{\mathrm{cr}}=$ critical shear stress for erosion (average and range). (GB $=$ Buitenschoor, $\mathrm{GS}=$ Galgenschoor, $\mathrm{PS}=$ Paardenschor $)$. 
same magnitude as the maximum flood currents on Buitenschoor. Maximum currents during neap tides are $15-40 \%$ lower than during spring tides. The sampling locations are situated in a sedimentary environment. Mean accumulation rates based on ${ }^{210} \mathrm{~Pb}$ profiles were $4.5 \mathrm{~mm}$ year ${ }^{-1}$ for Buitenschoor inside the dam (locations GBR, GB6, GB10), 2.4-3.9 mm year ${ }^{-1}$ for Paardenschor (PS1) and Galgenschoor (GS1, GS3) and zero for Buitenschoor outside the dam (GBL) (Wartel et al., 1998).

\section{Field sampling}

At each location 15 benthic samples were taken with a core $(\varnothing 4.5 \mathrm{~cm})$ to a depth of $10 \mathrm{~cm}$. Nine samples were sectioned into following intervals: $0-1 ; 1-3 ; 3-5 ; 5-10 \mathrm{~cm}$. Nine additional cores $(\varnothing 2.0 \mathrm{~cm})$ were sampled in September and sectioned in the same way. All samples were fixed with buffered formalin. For pigment analysis three random sediment samples of the top $1 \mathrm{~cm}$ were taken at each location with a corer $(\varnothing 2.0 \mathrm{~cm})$. Each sample, consisting of two sub-samples, was sectioned in the field in a surface sample $(0-0.5 \mathrm{~cm})$ and the layer of $0.5-1.0 \mathrm{~cm}$, and immediately frozen. For sediment granulometry the surface layer $(0-0.5 \mathrm{~cm})$ and the layer $0-10 \mathrm{~cm}$ were collected in the same way as for the sampling for pigments. One sample $(0-0.3 \mathrm{~cm})$ was taken for determination of the sediment bulk density and related sediment characteristics.

The critical shear stress for erosion, defined as the minimum applied bed shear stress required to initiate erosion and to remove sediment from the bed surface, was measured in situ at each location using the portable instrument SedErode (Mitchener et al., 1996). The basic principle of SedErode is that known shear stresses are applied to a mud surface and the bed response (suspended sediment concentration) is monitored. From this the critical shear stress is derived. Three erosion tests were performed at each location. The accuracy of SedErode measurements depends on several factors: the basic accuracy of the applied shear stress, which is $20 \%$ based on calibration against hot film shear stress probes, the size of the shear stress increments used during the test, and the microtopography of the sediment. For the April survey, the increment was approximately
$0.2 \mathrm{~N} \mathrm{~m}^{-2}$, which corresponded to the relatively hard sediments at this time. The sediments were considerably softer during the September survey, and it was decided to lower the increment to $0.1 \mathrm{~N} \mathrm{~m}^{-2}$ in order to obtain a higher accuracy at the low range of the SedErode instrument. This resulted in an error due to the chosen shear stress increment of \pm 0.1 and $\pm 0.05 \mathrm{~N} \mathrm{~m}^{-2}$, respectively.

\section{Laboratory measurements}

The $1000 \mu \mathrm{m}$ zoobenthic fraction was obtained by sieving the 15 samples $(\varnothing 4.5 \mathrm{~cm})$ through a $1000 \mu \mathrm{m}$ mesh and sorting after staining with 0.02 $\%$ Rose Bengal. In April, the $250 \mu \mathrm{m}$ and $500 \mu \mathrm{m}$ zoobenthic fractions were obtained by firstly sieving three of the vertically sectioned samples $(\varnothing 4.5 \mathrm{~cm})$ through a 250 and $500 \mu \mathrm{m}$ mesh, respectively. In September the nine smaller cores (Ø $2 \mathrm{~cm}$ ) were used to obtain estimates of the 250 and $500 \mu \mathrm{m}$ fractions (reduced sampling surface but increased number of replicates in order to capture better the spatial variability). The 500 and $250 \mu \mathrm{m}$ fractions were only analysed to a depth of $5 \mathrm{~cm}$, as previous observations showed hardly any benthos beneath a depth of $5 \mathrm{~cm}$ (personal observation). Organisms were counted and identified to species level, except Oligochaeta, Nematoda and Copepoda. For Annelids, often broken due to handling, only parts with a head structure were counted. Ash-free dry weight (AFDW) of the $1000 \mu \mathrm{m}$ fraction was measured by drying at $105^{\circ} \mathrm{C}$ for $12 \mathrm{~h}$ and ashing at $550{ }^{\circ} \mathrm{C}$.

The estimation of algal biomass was based on the observed content of chlorophyll $a$. The accessory pigment fucoxanthin was used as an indicator of diatom (Bacillariophyceae) biomass (Brotas \& Plante-Cuny, 1998; Paterson et al., 1998). Pigments were analysed by High-performance liquid chromatographic analysis (HPLC), using a modified method of Mantoura \& Llewellyn (1983). Sediment granulometry was measured by laser diffraction method (Malvern Mastersizer). Total organic content was determined by ignition loss.

\section{Statistical analyses}

For each location averages for both biological and environmental variables were calculated. Trophic structure of the zoobenthos (fraction $1000 \mu \mathrm{m}$ 
only) was determined by classifying the organisms into the following groups: surface-deposit feeders SDF (Corophium, spionids, Macoma, Manayunkia), subsurface-deposit feeders SSDF (Oligochaeta, Heteromastus) and omnivores (Nereis). These three groups accounted for $>99 \%$ of the trophic structure in the benthic community. The vertical distribution of the zoobenthos was expressed as the mean percentage of the abundance observed in each depth range at each location. Locations with less than five individuals of a certain species were omitted.

The relations between biotic and environmental parameters were determined using Spearman rank correlation. Since the same locations were sampled in both seasons, the general trend in seasonal variation of biotic and environmental variables was analysed using the Wilcoxon matched-pairs Signed rank test (Sokal \& Rohlf, 1981). Multivariate ordination techniques were used to investigate the relationship between zoobenthic species composition and pigments and environmental variables, respectively. A preliminary Detrended Correspondence Analysis on all 20 sampling locations yielded axes of short length (below $2 \mathrm{SD}$ ), so a linear ordination method, Redundancy Analysis (RDA) (Jongman et al., 1987; ter Braak, 1994) was applied further, using the computer program CANOCO 4.0 (ter Braak \& Smilauer, 1998). Benthos densities were $\log (x+1)$ transformed prior to analysis and were represented as the sum of the three sieve fractions.

\section{Results}

\section{Sediment characterisation}

Based on the median grain size all locations were classified as mud $(<63 \mu \mathrm{m})$ or very fine sand (63$125 \mu \mathrm{m}$ ) in both April and September, except for GBL $(>125 \mu \mathrm{m})$ (Table 1). Generally a significantly higher mud content and a lower median grain size was found in the top layer $(0-0.5 \mathrm{~cm})$ than in the $0-10 \mathrm{~cm}$ layer (Wilcoxon matchedpairs Signed-rank test $Z=2.538, p=0.01$ and $Z=2.165, p=0.03$, respectively, $n=20$ ), except for station GS2, where a more sandy top layer was observed in April.

The organic content of the sediment varied between 3 and $12 \%$, and was significantly correlated with the mud content of the top layer $(r=0.68, p=0.001, n=20)$. The bulk density of the sediment varied between 1256 and $1811 \mathrm{~kg} \mathrm{~m}^{-3}$ and was significantly negatively correlated with mud content of the top layer $(r=-0.64, p=0.002, n=20)$ and organic content $(r=-0.71, p=0.0004, n=20)$. None of the sediment characteristics was correlated with the elevation of the sampling locations.

No significant differences between April and September were observed for the different sediment characteristics, except for the critical shear stress for erosion (Table 2). The critical shear stress for erosion per location varied between 0.26 and $0.43 \mathrm{~N} \mathrm{~m}^{-2}$ in April and between 0.24 and $0.29 \mathrm{~N} \mathrm{~m}^{-2}$ in September. Especially at Buitenschoor and Paardenschor the mean values of the critical shear stress for erosion were higher in April than in September, whereas at Galgenschoor the values were similar during both surveys.

\section{Pigment contents}

Mean chlorophyll $a$ and fucoxanthin contents of the top layer $(0-0.5 \mathrm{~cm})$ were about seven times higher in April than in September (Table 2). Pigment contents were significantly higher in the surface layer $(0-0.5 \mathrm{~cm})$ in April (Wilcoxon matched-pairs Signed-rank test $Z=2.8, p=0.005$, $n=10$ ), whereas in September contents were similar in both layers. In April the highest pigment contents (surface layer) occurred on the Buitenschoor locations (26-86 $\mu \mathrm{g} \mathrm{g}^{-1}$ chlorophyll $a$ and $10-31 \mu \mathrm{g} \mathrm{g}^{-1}$ fucoxanthin, respectively), intermediate ones on the Paardenschor (14-43 and 6-19 $\left.\mu \mathrm{g} \mathrm{g}^{-1}\right)$ and lowest ones on the Galgenschoor (1.8-7.8 and 0.5-2.1 $\mu \mathrm{g} \mathrm{g}^{-1}$ ) (Fig. 2). In September the spatial variation and the pigment contents were much lower. The range of chlorophyll $a$ and fucoxanthin contents on all mudflats was 2.2-6.9 and $0.7-2.4 \mu \mathrm{g} \mathrm{g}^{-1}$, respectively; highest values were again found on the Buitenschoor mudflat.

The ratio of fucoxanthin to chlorophyll $a$ in the $0-0.5 \mathrm{~cm}$ layer was different among the mudflats in April, but was relatively constant within each mudflat. The highest ratios were measured on the Paardenschor, indicating the highest diatom dominance. In September the ratios were more comparable among the mudflats, with extreme values at the locations GS3 and PS3, respectively. 
Table 2. Comparison of sediment characteristics, pigment contents (chlorophyll $a$ and fucoxanthin), and zoobenthos characteristics (species richness, abundance, biomass) between spring (April) and autumn (September)

\begin{tabular}{|c|c|c|c|c|}
\hline & April $(n=10)$ & September $(n=10)$ & $Z$-value & $p$-value \\
\hline \multicolumn{5}{|l|}{ Sediment characteristics } \\
\hline Density of the sediment $\left(\mathrm{kg} \mathrm{m}^{-3}\right)$ & $1477 \pm 176$ & $1525 \pm 110$ & 0.7645 & NS \\
\hline Median grainsize $0-10 \mathrm{~cm}(\mu \mathrm{m})$ & $59.3 \pm 31.1$ & $54.9 \pm 30.3$ & 0.7644 & NS \\
\hline Mud content $0-10 \mathrm{~cm}(\%)$ & $54.1 \pm 15.1$ & $57.4 \pm 15.2$ & 1.0783 & NS \\
\hline Median grainsize $0-0.5 \mathrm{~cm}(\mu \mathrm{m})$ & $49.9 \pm 27.9$ & $45.0 \pm 28.0$ & 0.2548 & NS \\
\hline Mud content $0-0.5 \mathrm{~cm}(\%)$ & $60.5 \pm 14.7$ & $65.9 \pm 14.4$ & 0.3567 & NS \\
\hline Organic matter $(\%)$ & $7.4 \pm 3.1$ & $5.9 \pm 1.5$ & 1.7838 & NS \\
\hline Critical erosion shear stress $\left(\mathrm{N} \mathrm{m}^{-2}\right)$ & $0.33 \pm 0.06$ & $0.27 \pm 0.02$ & 2.6500 & $* *$ \\
\hline \multicolumn{5}{|l|}{ Pigment contents } \\
\hline Chlorophyll $a 0-0.5 \mathrm{~cm}\left(\mu \mathrm{g} \mathrm{g}^{-1}\right)$ & $34.5 \pm 31.0$ & $4.27 \pm 1.34$ & 2.5992 & ** \\
\hline Chlorophyll a $0.5-1.0 \mathrm{~cm}\left(\mu \mathrm{g} \mathrm{g}^{-1}\right)$ & $8.13 \pm 6.12$ & $4.06 \pm 1.80$ & 1.8857 & NS \\
\hline Fucoxanthin $0-0.5 \mathrm{~cm}\left(\mu \mathrm{g} \mathrm{g}^{-1}\right)$ & $12.5 \pm 10.9$ & $1.70 \pm 0.53$ & 2.4286 & $* *$ \\
\hline Fucoxanthin $0.5-1.0 \mathrm{~cm}\left(\mu \mathrm{g} \mathrm{g}^{-1}\right)$ & $2.74 \pm 2.41$ & $1.54 \pm 0.57$ & 1.7838 & NS \\
\hline \multicolumn{5}{|l|}{ Zoobenthos $1000 \mu \mathrm{m}$} \\
\hline Species richness $\left(N_{0}\right)$ & $3.8 \pm 2.6$ & $6.7 \pm 2.2$ & 2.3102 & * \\
\hline Total abundance (ind $\mathrm{m}^{-2}$ ) & $3311 \pm 3383$ & $16675 \pm 12431$ & 2.7011 & ** \\
\hline Total biomass (g AFDW $\mathrm{m}^{-2}$ ) & $1.307 \pm 1.606$ & $6.689 \pm 5.447$ & 2.7011 & ** \\
\hline Surface deposit feeder abundance (ind $\mathrm{m}^{-2}$ ) & $289 \pm 248$ & $7675 \pm 5784$ & 2.7011 & ** \\
\hline Sub-surface deposit feeder abundance (ind $\mathrm{m}^{-2}$ ) & $2905 \pm 3337$ & $8228 \pm 10437$ & 2.4973 & * \\
\hline Omnivore abundance (ind $\mathrm{m}^{-2}$ ) & $122 \pm 220$ & $755 \pm 785$ & 2.3664 & * \\
\hline \multicolumn{5}{|l|}{ Zoobenthos $500 \mu \mathrm{m}$} \\
\hline Species richness $\left(\mathrm{N}_{0}\right)$ & $3.6 \pm 1.0$ & $4.8 \pm 1.8$ & 1.6103 & NS \\
\hline Total abundance (ind $\mathrm{m}^{-2}$ ) & $35567 \pm 25391$ & $64405 \pm 45028$ & 1.9876 & * \\
\hline \multicolumn{5}{|l|}{ Zoobenthos $250 \mu \mathrm{m}$} \\
\hline Species richness $\left(\mathrm{N}_{0}\right)$ & $4.1 \pm 1.2$ & $6.8 \pm 1.8$ & 2.5205 & * \\
\hline Total abundance (ind $\mathrm{m}^{-2}$ ) & $162493 \pm 151782$ & $339460 \pm 228706$ & 2.1915 & * \\
\hline
\end{tabular}

Mean and Standard Deviation of the parameters in both months with the $Z$-value and associated probability of the Wilcoxon matched pairs signed rank test are given. NS $=$ not significant, ${ }^{*} p<0.05,{ }^{* *} p<0.01$.
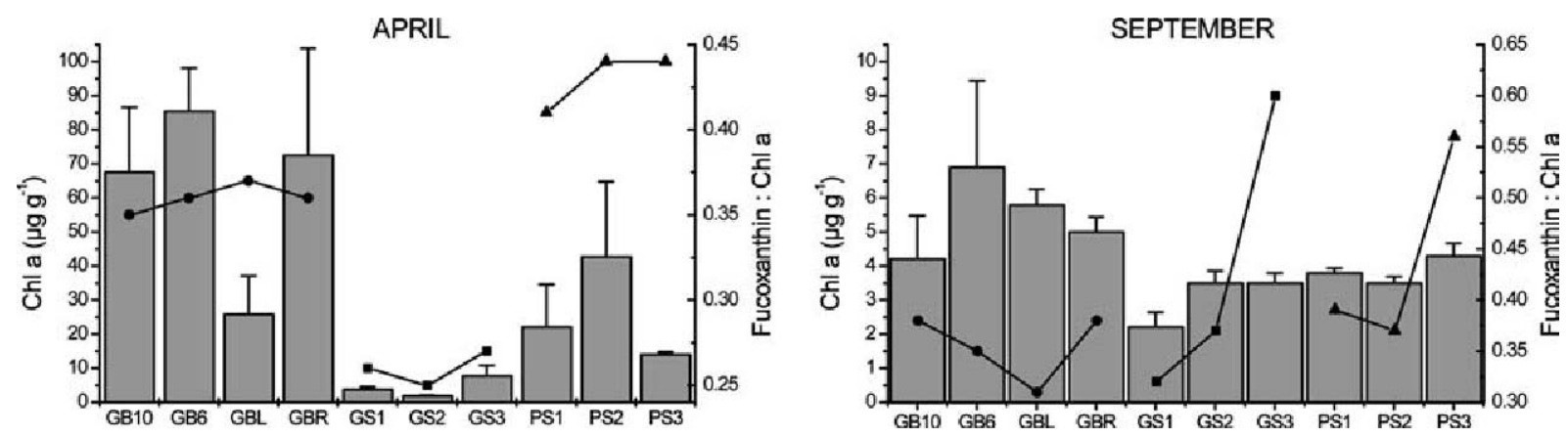

Figure 2. Chlorophyll $a$ contents (bars) and ratio of Fucoxanthin to Chl $a$ (lines, presented for each mudflat separately) in the top sediment layer $(0-0.5 \mathrm{~cm})$ at the ten sampling locations in April and September respectively. $(\mathrm{GB}=$ Buitenschoor, $\mathrm{GS}=\mathrm{Galgenschoor}$, $\mathrm{PS}=$ Paardenschor). Note the difference in scale between April and September. 
The ratio of fucoxanthin to chlorophyll $a$ in the deeper layer $(0.5-1.0 \mathrm{~cm})$ was similar as the one for the top layer.

\section{Characterisation of the benthic fauna}

In the $1000 \mu \mathrm{m}$ fraction of the zoobenthos a total of 13 species were found ( 7 annelids, 3 crustaceans, 3 molluscs). Eteone longa, Corophium lacustre, Mya arenaria and Crangon crangon were only observed once; one individual of Polydora sp. was observed in September at four locations. Total abundance and total biomass of the $1000 \mu \mathrm{m}$ fraction largely varied among the ten locations in both April and September, being highest in both months on Paardenschor, and lowest on Galgenschoor (Figs 3 and 4). Oligochaeta in April were the dominant taxon representing $81 \%$ of the total abundance. In terms of biomass Oligochaeta were less dominant (Fig. 4). Species richness (number of species $\mathrm{N}_{0}$ ) was significantly higher in September. Abundance and biomass showed also a significant (5-fold) increase. Species dominance then clearly differed among mudflats (Figs 3 and 4). Corophium volutator dominated the community at Buitenschoor (70 and $51 \%$ of the total abundance and biomass, respectively). Heteromastus filiformis was more dominant at Paardenschor (60 and $66 \%$ of the total abundance and biomass, respectively). On both mudflats, Macoma balthica and Nereis diversicolor contributed substantially to the total biomass. Lowest abundance and biomass were observed at Galgenschoor; only at GS2 values were comparable with the other two mudflats.

SSDF dominated numerically the benthic community in April at most locations (Fig. 5). In terms of biomass, also SDF and omnivores were of relative importance at some locations. In September SDF became numerically more dominant, especially at the Buitenschoor locations. SSDF still dominated on Galgenschoor and Paardenschor. A similar pattern was observed for biomass in September.

Total abundance of the $500 \mu \mathrm{m}$ fraction of the benthos was lowest at Galgenschoor (Fig. 6). In April this fraction of the benthos was mainly dominated by Oligochaeta $(52 \%$ of the total abundance). Manayunkia aestuarina was also a dominant species of the benthic community at Buitenschoor (54\% of the total abundance). At some locations Nematoda were observed in this fraction of the benthos. Mean total abundance doubled significantly in September as compared to April. Oligochaeta still dominated $(62 \%$ of the total abundance), but also other macrobenthic species appeared more frequently, such as $C$. volutator, especially predominantly present at Buitenschoor, $H$. filiformis, $N$. diversicolor and Hydrobia ulvae. Hardly any macrobenthic species were found in the $500 \mu \mathrm{m}$ fraction at the Galgenschoor site. Both M. aestuarina and Nematoda were not found in the $500 \mu \mathrm{m}$ fraction in September.

The benthos of the $250 \mu \mathrm{m}$ fraction in April was dominated by Nematoda $(65 \%$ of the total abundance), and to a lesser extent by $M$. aestuarina and Copepoda (Fig. 6). At Galgenschoor, this fraction was nearly devoid of benthos. Mean total abundance increased significantly in September, especially at Buitenschoor. This was mainly due to an increase of Oligochaeta and $M$. aestuarina; also $C$. volutator was observed in this fraction. Copepoda abundances increased in September, whereas Nematoda abundances on average decreased.

\section{Vertical distribution of the benthic fauna}

The majority of the benthic infauna was found in the upper $3 \mathrm{~cm}$, but a change in distribution from a higher abundance in the upper layer of the sediment $(0-1 \mathrm{~cm})$ in April towards a deeper distribution in September was observed for several smaller taxa (Fig. 7). In April, Oligochaeta from 250 to $500 \mu \mathrm{m}$ fractions were most abundant in the top $0-1 \mathrm{~cm}$ layer of the sediment (about $70 \%$ ), whereas Oligochaeta from the $1000 \mu \mathrm{m}$ fraction were equally present in the top $0-1 \mathrm{~cm}$ and the $1-3 \mathrm{~cm}$ layers. In September, the 1-3 cm layer became relatively more important for all fractions of Oligochaeta. M. aestuarina shifted from a $85 \%$ occurrence in the top $0-1 \mathrm{~cm}$ layer in April to a $60 \%$ occurrence in the 1-3 cm layer in September. Most Nematodes occurred in the top 0-1 cm layer in both months, but in September relatively more individuals also occurred in the deeper layers. Copepoda were found almost exclusively in the upper layer of the sediment in both seasons. The macrobenthic species, that were only dominant in September, showed a different vertical distribution 

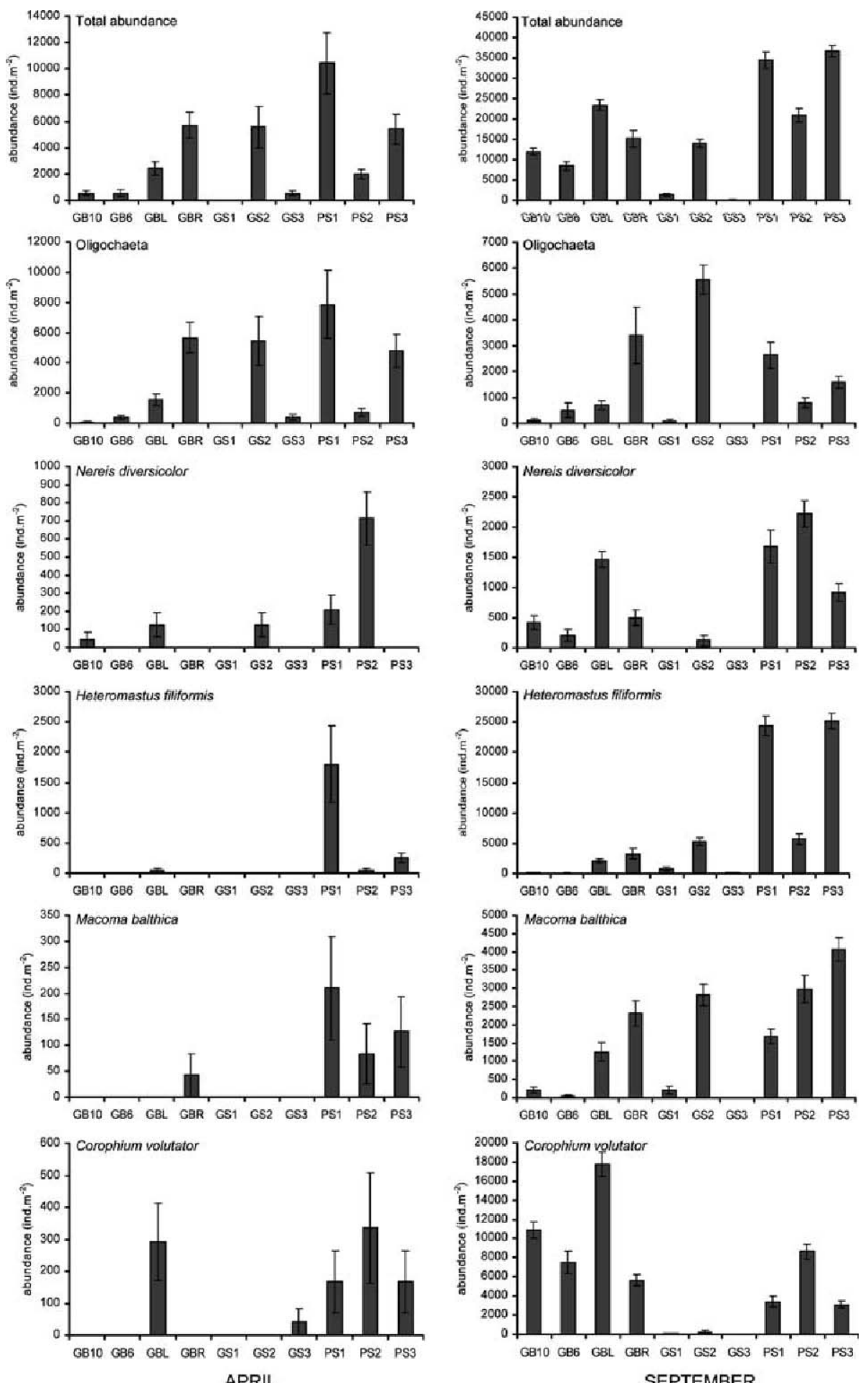

Figure 3. Total abundance and abundance of the dominant macrofauna species (1000 $\mu \mathrm{m}$ fraction, ind $\left.\mathrm{m}^{-2} \pm \mathrm{SD}\right)$ at the ten sampling locations in April and September, respectively. Note the differences in scale between April and September. 


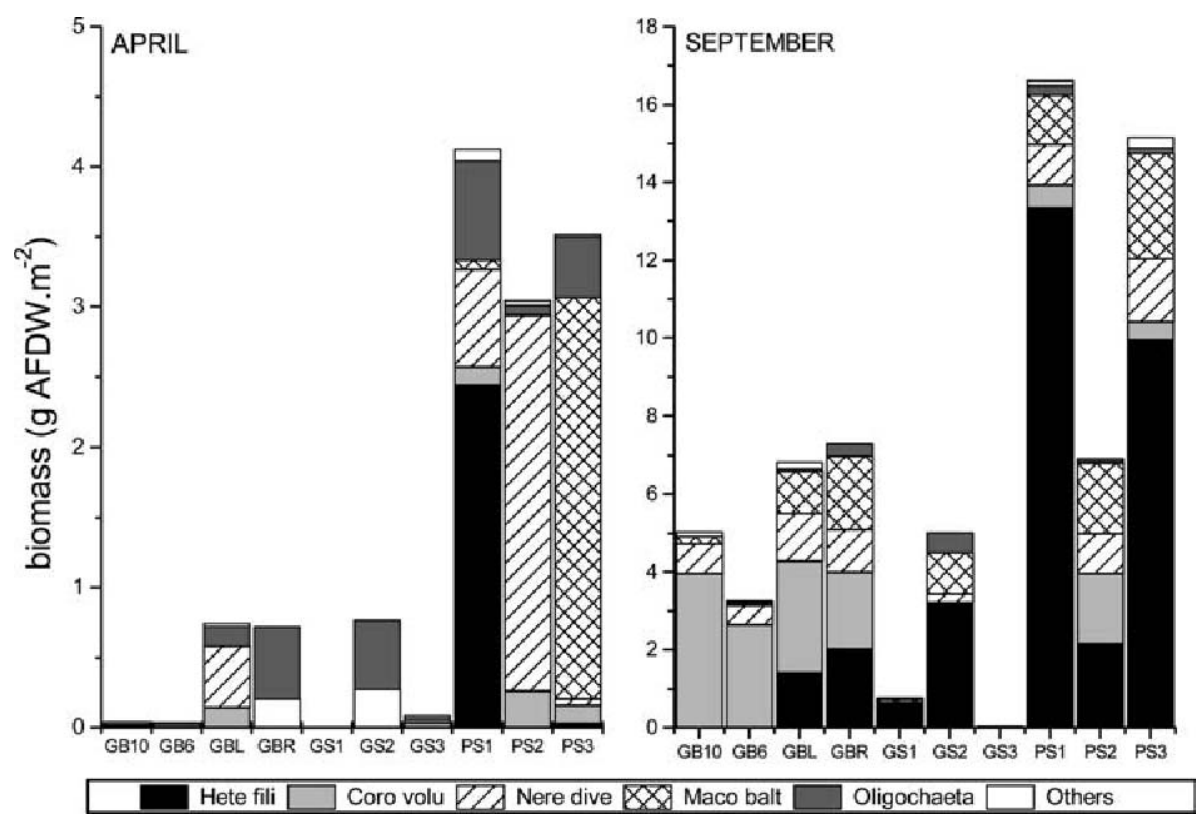

Figure 4. Biomass ( $\mathrm{g}$ AFDW m${ }^{-2}$ ) of the five dominant macrobenthic species for the $1000 \mu \mathrm{m}$ fraction at the 10 locations in April and September, respectively. Hete fili $=$ Heteromastus filiformis, Coro volu $=$ Corophium volutator, Nere dive $=$ Nereis diversicolor, Maco balt = Macoma balthica . Note the difference in scale between April and September.

pattern (Fig. 8). All fractions of C. volutator occurred almost exclusively in the top $0-1 \mathrm{~cm}$ layer of the sediment. H. filiformis showed a different pattern with higher abundances occurring in the deeper layers of the sediment. $N$. diversicolor was mainly present in the top $3 \mathrm{~cm}$ of the sediment, especially in the $1-3 \mathrm{~cm}$ layer. The grazer $H$. ulvae clearly preferred the top layer. In terms of feeding guilds, surface deposit feeders where dominant in the $0-1 \mathrm{~cm}$ layer, whereas sub-surface deposit feeders had their optimum at $1-3 \mathrm{~cm}$ and also occurred frequently in the 3-5 and 5-10 cm layer.

\section{Relationships between biotic and environmental parameters}

In April, both chlorophyll $a$ and fucoxanthin contents were strongly positively correlated with each other and with height of the location, and negatively correlated with the bulk density of the sediment (Table 3). In September only chlorophyll $a$ was positively correlated with elevation, whereas the correlation between both pigments was less significant.

Benthic species that were typically found at the top layer of the sediment (Figs. 7 and 8) were positively correlated with pigment contents. C. volutator, nearly absent in April, showed a very high correlation with elevation and chlorophyll $a$ contents in September. The observed Corophium abundances were also significantly correlated with the decrease in chlorophyll $a$ contents between April and September $\left(\mathrm{Chl} \mathrm{a} \mathrm{apr}-\mathrm{Chl} \mathrm{a} \mathrm{a}_{\mathrm{sep}}\right)(r=0.90$, $p=0.0003)$. M. aestuarina and Copepoda abundances were positively correlated with elevation and pigment contents both in April and September, and also with the chlorophyll $a$ decrease $(r=0.68, p=0.03$ and $r=0.77, p=0.01$, respectively).

The total biomass of the macrobenthos was significantly correlated with mud content in September (Table 3). H. filiformis, Oligochaeta and Nematoda were significantly more abundant in more muddy sediments.

Based on both months together, a significantly positive correlation was observed between critical shear stress for erosion and chlorophyll $a$ and fucoxanthin contents $(r=0.61, p=0.004$ and $r=0.53, p=0.017$, respectively, $n=20$ ). Only the GB6 location had deviating results with high pigment contents but relatively low critical shear stresses for erosion. Our results indicated that sediments with lower bulk density, i.e. a higher mud fraction, generally had a lower critical shear stress for erosion. However, it should be 


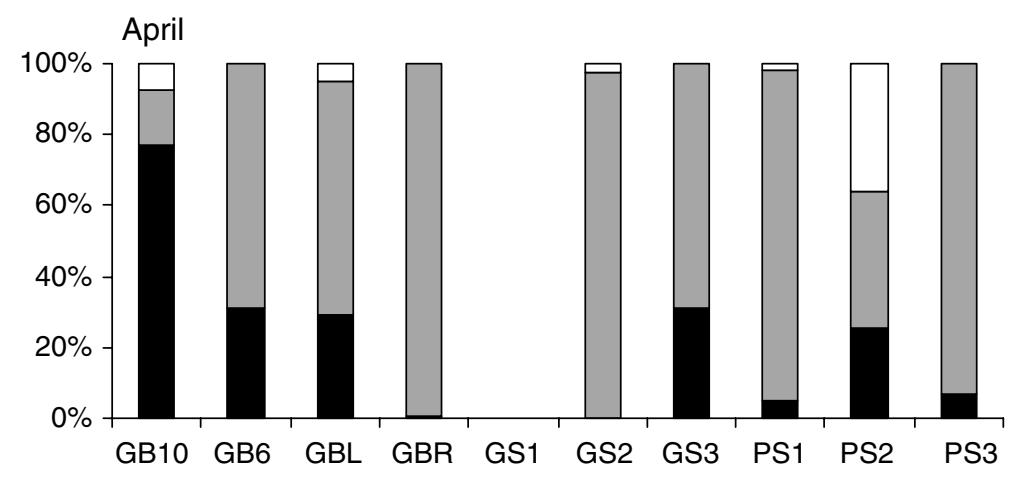

- Surface deposit $\square$ Sub-surface deposit $\square$ Omnivore

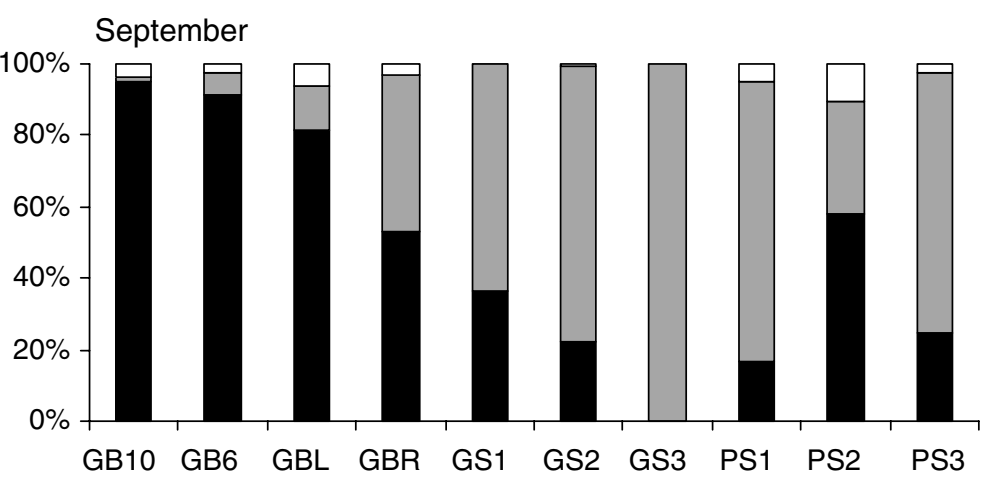

— Surface deposit $\square$ Sub-surface deposit $\square$ Omnivore

Figure 5. Relative contribution of each feeding type to the total abundance of the benthic macrofauna (fraction $1000 \mu \mathrm{m}$ ) at each location in April (top) and September (bottom) respectively. Feeding types considered are surface deposit feeders, sub-surface deposit feeders and omnivores. In April no macrofauna was observed at location GS1.

emphasised that the data show considerable scatter within each location, which is related to the measurement procedure itself, to the heterogeneity of the sediments on the mudflats and to the occurrence of organic matter of diverse origin.

Figure 9 displays the RDA ordination diagram (triplot) with the major variation in the 20 sampling occasions across space and time. The first two axes of the RDA had eigenvalues of 0.49 and 0.19 , respectively, and explained $68 \%$ of the species variation. They were both significant by Monte Carlo statistics and represented $85 \%$ of the species-environment relation. The positions of the centroids in the diagram for April and September showed that the first axis mainly represented the change with time: all April stations, except PS2, were situated on the right-side, and all September stations, except GS3, on the left-side of the diagram. The second axis mainly represented the change with elevation and with correlated pigment contents. Since pigment contents clearly had a seasonal variation, the second axis also partly explained the difference between April and September. Benthic species situated in the upper left quadrant were species which were abundant during both months (e.g. M. aestuarina, Copepoda, Nematoda), whereas benthic species situated in the lower left quadrant were species which were only abundant in September.

\section{Discussion}

In this study we investigated the intertidal benthic communities in the low salinity zone of the Schelde estuary in relation to their sedimentary 

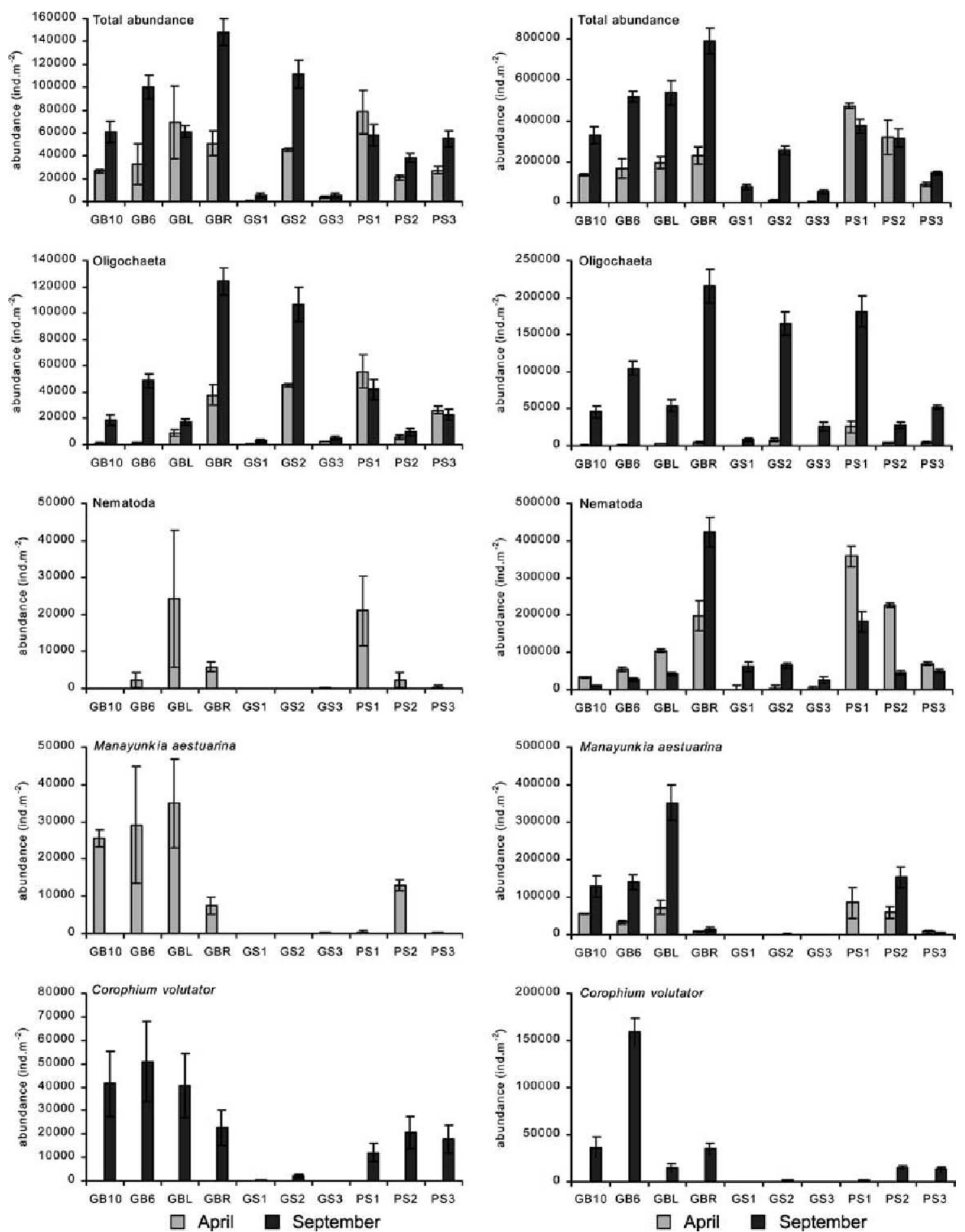

Figure 6. Total abundance and abundance of the dominant benthic fauna species (left graphs $=500 \mu \mathrm{m}$ fraction, ind $\mathrm{m}^{-2} \pm \mathrm{SD}$, right graphs $=250 \mu \mathrm{m}$ fraction, ind $\mathrm{m}^{-2} \pm \mathrm{SD}$ ) at the ten sampling locations in April and September respectively. Note the differences in scale. 

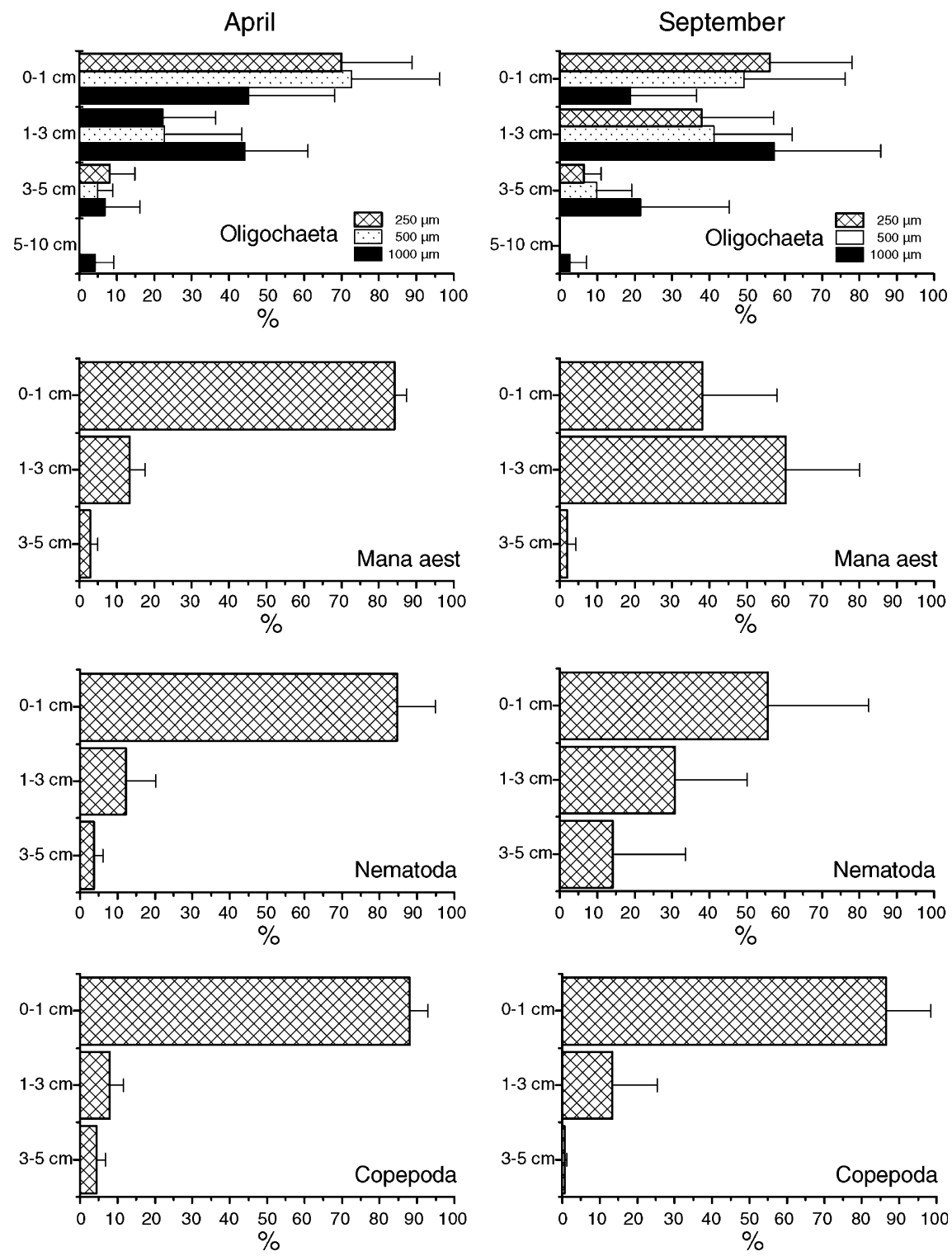

Figure 7. Vertical profiles $(0-5 \mathrm{~cm})$ with mean proportions $(\%)$ of the total numbers $( \pm \mathrm{SD})$ of Oligochaeta (Olig), Manayunkia aestuarina (Mana), Nematodes (Nema) and Copepoda (Cope) in April and September. For Oligochaeta each fraction (250, 500 and $1000 \mu \mathrm{m})$ is given, other species based on the $250 \mu \mathrm{m}$ fraction.

environment. It emerged that the nature of the sediment (in terms of granulometric characterization, organic matter) did not fully explain the substantial spatial and temporal (seasonal) variability in the benthos (pigment contents and benthic fauna). Sediment characteristics were spatially and temporally relatively homogeneous among the sampling locations, all characterized by a high proportion of mud. The observed benthic variability is likely to be linked to other environmental conditions.

Pigment content variability

In April, much higher chlorophyll $a$ and fucoxanthin contents were observed as compared to September, which can be attributed to the spring bloom of diatoms on the intertidal mudflats, resulting in a 

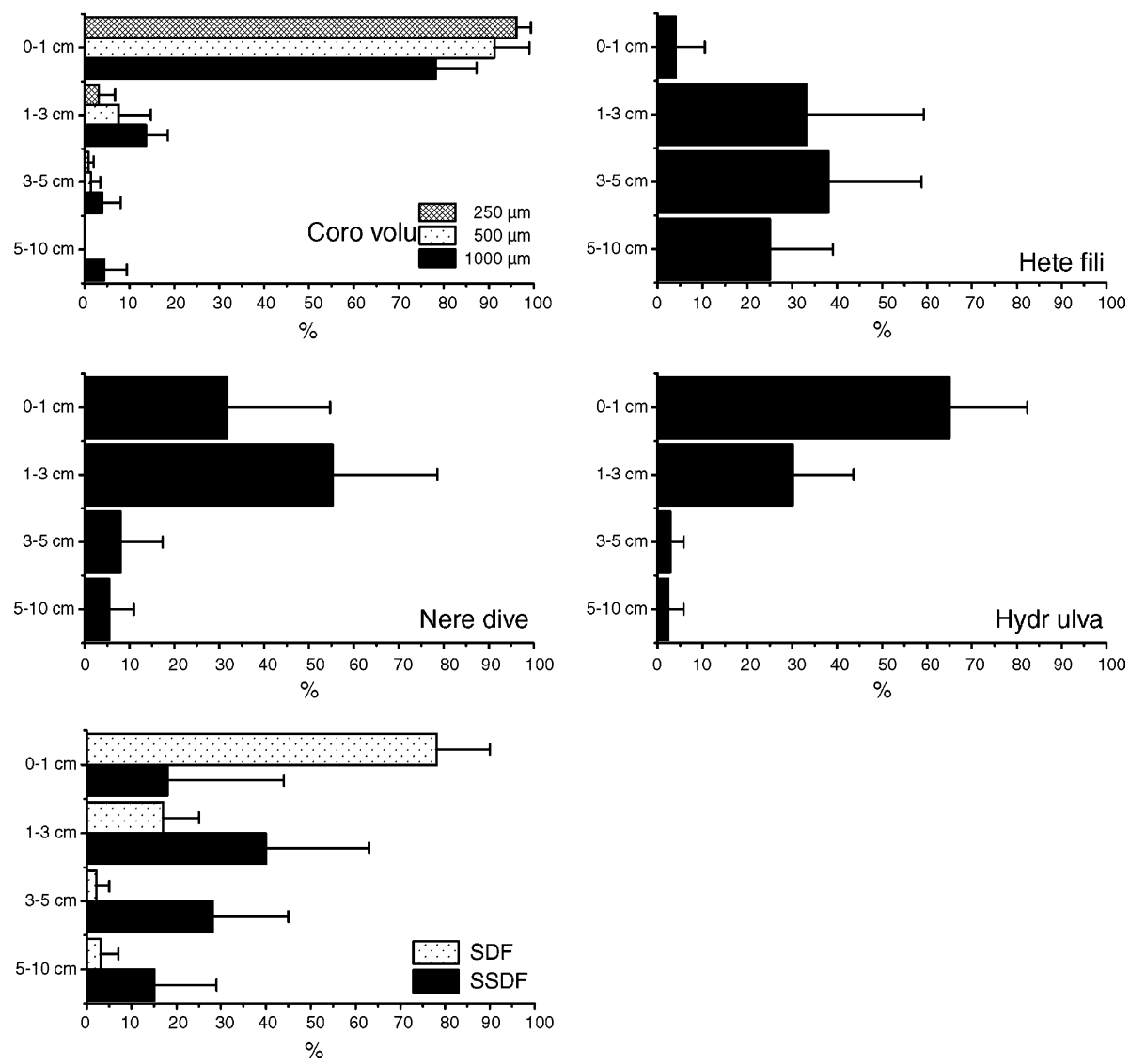

Figure 8 . Vertical profiles $(0-10 \mathrm{~cm})$ with mean proportions $(\%)$ of the total numbers $( \pm \mathrm{SD})$ of the dominant macrobenthic species and trophic groups in September: Corophium volutator (Coro volu), Nereis diversicolor (Nere dive), Heteromastus filiformis (Hete fili), Hydrobia ulvae (Hydr ulva), surface deposit feeders (SDF) and sub-surface deposit feeders (SSDF). For C. volutator data for each fraction $(250,500$ and $1000 \mu \mathrm{m})$ are presented, other species based on the $1000 \mu \mathrm{m}$ fraction only.

visible microalgal mat, as also observed in the polyhaline zone of the Schelde estuary (De Jong \& De Jonge, 1995; Barranguet et al., 1997; de Brouwer et al., 2000). The lower pigment contents in September may be ascribed to grazing by benthic invertebrates, as indicated by the relation between the density of some typically surface feeding species (e.g. C. volutator) and a decrease in microphytobenthos biomass. There is substantial evidence indicating that microphytobenthos (benthic diatoms) are the primary food resource for many benthic macrofauna species (e.g. Herman et al. 2000). Increased grazing by zoobenthos, in particular C. volutator, might indeed decrease microalgae populations (Gerdol \& Hughes, 1994a; Hagerthey et al., 2002, De Deckere, 2003). Chlorophyll levels in intertidal sediments at the Bay of Fundy declined as population size of $C$. volutator increased through summer (Hargrave et al., 1983).

A clear relation with height (exposure time) was observed with highest pigment contents in the upper shore sediments (Buitenschoor mudflat), intermediate contents in the middle shore sediments (Paardenschor mudflat) and lowest contents at the lower shore sediments (Galgenschoor mudflat). This is in accordance with several other observations on intertidal mudflats (e.g. Underwood \& Paterson, 1993; De Jong \& De Jonge, 1995; Barranguet et al., 1997). The locations on the Galgenschoor were situated very low in the intertidal zone and therefore flooded most of the time. These sites will experience the stress of light limitation, especially being situated in a high turbidity zone of the estuary (MacIntyre \& Cullen, 1996). 
Table 3. Spearman correlation coefficients between biotic and environmental parameters (top $0-0.5 \mathrm{~cm}$ sediment layer only) for April and September means

\begin{tabular}{|c|c|c|c|c|c|c|c|c|c|c|}
\hline & \multicolumn{4}{|c|}{ April $(n=10$ locations $)$} & \multicolumn{6}{|c|}{ September ( $n=10$ locations) } \\
\hline & Fuco & Chl $a$ & Bulk & Height & Fuco & Chl $a$ & Bulk & Height & Mud & Median \\
\hline \multicolumn{11}{|l|}{ Biotic components } \\
\hline Chlorophyll $a$ & $0.99^{* * *}$ & & $-0.88^{* * *}$ & $0.85^{* * *}$ & $0.73^{*}$ & & & $0.79^{* *}$ & & \\
\hline Fucoxanthin & & $0.99^{* * *}$ & $-0.88^{* * *}$ & $0.85^{* * *}$ & & $0.73^{*}$ & & & & \\
\hline \multicolumn{11}{|l|}{ Benthos abundance $1000 \mu \mathrm{m}$} \\
\hline Benthos biomass $1000 \mu \mathrm{m}$ & & & & & & & & & $0.62^{*}$ & $-0.71^{*}$ \\
\hline Benthos abundance $500 \mu \mathrm{m}$ & & & & & & & & $0.62^{*}$ & & \\
\hline Benthos abundance $250 \mu \mathrm{m}$ & & $0.66^{*}$ & & & & & & $0.73^{*}$ & & \\
\hline SDF abundance & & & & & & & $0.92^{* * *}$ & $0.72^{*}$ & & \\
\hline SSDF abundance & & & & & & & & & $0.71^{*}$ & $-0.66^{*}$ \\
\hline \multicolumn{11}{|l|}{ Omnivore abundance } \\
\hline C. volutator abundance & & & & & & $0.82^{* *}$ & $0.83^{* *}$ & $0.99^{* * * *}$ & & \\
\hline H. filiformis abundance & & & & & & & & & & $-0.62^{*}$ \\
\hline Oligochaeta abundance & & & & & & & & & $0.66^{*}$ & \\
\hline M. aestuarina abundance & $0.64^{*}$ & $0.64^{*}$ & $-0.65^{*}$ & & & $0.71^{*}$ & $0.87^{* *}$ & $0.96^{* *}$ & & \\
\hline Copepoda abundance & $0.94^{* * *}$ & $0.94^{* * *}$ & $-0.79^{* *}$ & $0.94^{* * *}$ & & $0.62^{*}$ & & $0.92^{* * *}$ & & \\
\hline Nematodes abundance & & & & & & & & & $0.62^{*}$ & $-0.67^{*}$ \\
\hline
\end{tabular}

Only significant correlations $\left({ }^{* * *} p<0.005 ;{ }^{* *} p<0.01 ;{ }^{*} p<0.05\right)$ are shown.

Benthic species abundance represents the sum of the three fractions $(1000,500$ and $250 \mu \mathrm{m})$. (Fuco = fucoxanthin; $\mathrm{Chl} a=$ chlorophyll $a$; Bulk = bulk density of the sediment; Mud = mud content; Median = median grain size).

Normally siltier and finer sediments contain more microphytobenthos than sandy sediments (De Jong \& De Jonge, 1995; Lucas \& Holligan, 1999). The more sandy GBL location in April had indeed lower pigment contents as compared to the more muddy locations on the Buitenschoor mudflat (same height).

The critical shear stress for erosion of the upper layer of the sediments in this study showed a difference between both seasons and a positive correlation with pigment contents. This is in accordance with a number of field and laboratory studies demonstrating that sediment-inhabiting algae, particularly epipelic diatoms and cyanobacteria, can protect sediment from erosion and stabilise cohesive sediments through production of extracellular polymeric substances (Yallop et al., 1994). The lower values for critical shear stress for erosion in September might be the result of lower pigment contents (no algal mat present) or of a higher macrofauna activity (Luckenback, 1986; Widdows et al., 2000; de Deckere et al., 2001) at that time. In the literature both stabilizing as well as destabilizing forces are ascribed to macrofauna, in some cases by a single species. For instance, C. volutator may increase directly sediment stability by binding particles with the secretions used to construct their tubes or burrow walls (Meadows et al., 1990; Mouritsen et al., 1998). In contrast, Gerdol \& Hughes (1994a) found that C. volutator caused destabilization of the sediment bed due to grazing on microphytobenthos and reworking of the sediment by burrowing and tube formation. There was further no evidence in our study that (de)stabilization of the sediment resulted in a change in mud content. In our study the data on the critical shear stress for erosion showed considerable variation within each location, and the relatively low resolution of the SedErode instrument call for a careful interpretation of the results. Concluding, the spatial variability in pigment contents was mainly attributed to the difference in elevation between the study sites, rather than differences in mud content. No clear effect of biostabilization by micro-algae on mud content of the sediment was observed, and mud content seemed to be mainly determined by (local) hydrodynamic conditions. 


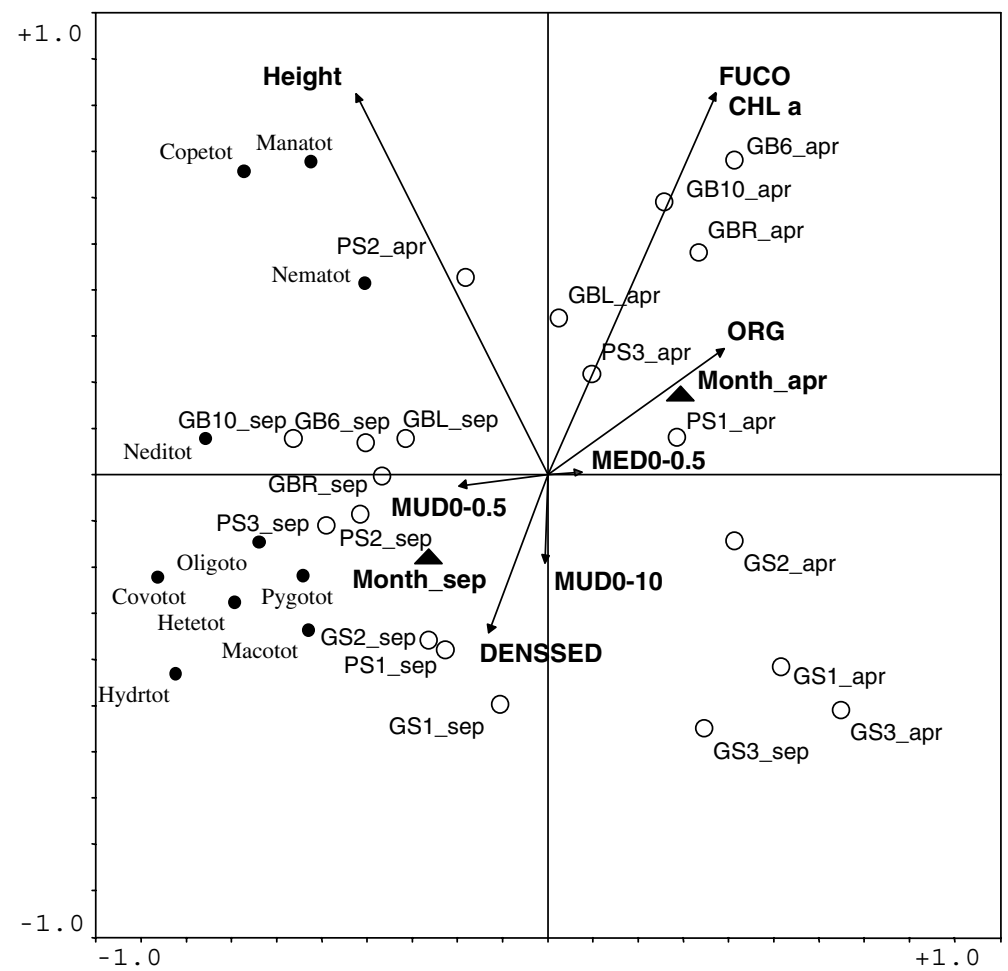

Figure 9. RDA ordination diagram showing the spatial and temporal variation of the 20 sampling locations. The first four eigenvalues are $0.49,0.19,0.06$ and 0.03 . Shown are centroids of month (April = Month_apr and September $=$ Month_sep) and environmental variables as arrows. Environmental variables are: height, chlorophyll a and fucoxanthin contents of the $0-0.5 \mathrm{~cm}$ layer (CHL $a$ and FUCO) mud content of the $0-0.5 \mathrm{~cm}$ and the $0-10 \mathrm{~cm}$ layers (MUD0-0.5 and MUD0-10), median grain size of the $0-0.5 \mathrm{~cm}$ layer (MED0-0.5), organic matter (ORG), and bulk density of the sediment (DENSSED). Benthic species are represented by circles and should be interpreted as arrows. Benthic species represents the sum of abundance of the three fractions (1000, 500 and $250 \mu \mathrm{m})$ together. $($ Copetot $=$ Copepoda; Covotot $=$ Corophium volutator; Hetetot $=$ Heteromastus filiformis, Hydrtot $=$ Hydrobia ulvae; Macotot $=$ Macoma balthica $;$ Manatot $=$ Manayunkia aestuarina $;$ Nematot $=$ Nematoda $;$ Neditot $=$ Nereis diversicolor $;$ Oligotot $=$ Oligochaeta; Pygotot $=$ Pygospio elegans).

\section{Benthic fauna variability}

We have found considerable spatial and temporal variations in abundance, biomass and vertical distributions in the sediment fauna that are likely to be linked to environmental fluctuations. The benthic infauna was dominated by only a few, relatively small benthic species, but clearly showed seasonal variations with low species richness, abundance and biomass in April (spring) and significantly higher abundance and biomass in September (autumn). In April the benthic community in the 1000 and $500 \mu \mathrm{m}$ fraction was mainly dominated by Oligochaeta, the $250 \mu \mathrm{m}$ fraction by typically meiobenthic species (Copepoda and Nematoda) and Oligochaeta. Polychaetes, crustaceans and bivalves were nearly absent
(Galgenschoor, Buitenschoor) or observed only in very low abundances (Paardenschor). In September these taxonomic groups became dominant in the $1000 \mu \mathrm{m}$ fraction at most locations, with C. volutator (Buitenschoor) and H. filiformis (Paardenschor, Galgenschoor) dominating; also $N$. diversicolor and $M$. balthica were observed at most locations. Also in the smaller fractions these species appeared in September, especially C. volutator. The lack of or the very low abundance of several macrobenthic species in April can be attributed to the lower salinity conditions in winter and spring in this zone of the estuary, as was also demonstrated by long-term monthly observations at the GBL location (1990-1999, personal observation). In estuarine systems with high seasonal variability in river flow rate, the upper/middle 
estuarine fauna may switch each year between an oligohaline and a mesohaline fauna, with high mortalities in between (e.g. Marchand \& Gascuel, 1988; Ysebaert et al., in preparation), which result in communities that seldom progress beyond early benthic-community succession. In April the benthic community was very similar as the communities observed in the oligohaline and freshwater tidal zone of the Schelde estuary, characterized by a year round dominance of Oligochaeta (Seys et al., 1999a, b). In September the locations got colonized by euryhaline species such as $C$. volutator, $H$. filiformis and $M$. balthlica, reflecting typically mesohaline macrobenthic communities (e.g. Ysebaert et al., 2003). The distribution of organisms within estuaries is therefore influenced more highly by variation than by absolute salinity regimes (Wolff, 1983; Attrill, 2002). The dominant macrobenthic taxa observed in this study are generally considered to be opportunistic in nature, adapted to quickly recolonize after disturbance (e.g. low salinity), and they are common in a variety of mid-estuarine, river-dominated systems, especially with moderate anthropogenic impacts. This implies also that patterns are not simply reflecting local conditions but also will be influenced by recruitment fluctuations on a larger scale. In the polyhaline zone of the Schelde estuary intra-annual variation is less pronounced, and the benthic community is often characterized by larger, long-living species (e.g. Arenicola marina, Cerastoderma edule) (personal observations). Although the data were not analysed as such, the size spectra of the zoobenthos in our study appeared to be dominated by much smaller individuals as compared to the polyhaline zone, and further research on the biomass size spectra (in relation to functional group analyses and vertical mixing) of benthic assemblages along the salinity gradient (or other environmental conditions) might reveal important implications for ecosystem function because it may influence foodchain efficiency and energy transfer (e.g. SaizSalinas \& Ramos, 1999; Duplisea, 2000).

The importance of sediment composition in determining (spatial) distribution patterns of estuarine benthic fauna has long been recognized (Snelgrove \& Butman, 1994). The investigated mud flats in the lower salinity zone of the Schelde estuary are predominantly characterized by high mud contents, and sediment characteristics, being similar at most locations, only explained to a minor part the spatial distribution of the benthic species. Sub-surface deposit feeders, like Oligochaeta and $H$. filiformis, were positively correlated with the mud content of the sediment. It is argued that the hydrodynamical conditions and the elevation of the locations further explained the macrobenthic species occurrence. The higher tidal currents observed at the Galgenschoor sampling locations, together with a position low in the intertidal zone and a steep slope, most likely resulted in a higher mud dynamic and thus a less favourable environment (higher stress) for benthos, especially at the two lowest locations (GS1, GS3). On the other hand, the elevation of the sampling locations was the main factor controlling the occurrence of microphytobenthos, which is a primary food resource for many benthic macrofauna (e.g. Herman et al., 2000). A strong correlation was observed between chl $a$ and the dominant surface deposit feeders $(C$. volutator, $M$. aestuarina, Copepoda). The lack of suspension feeders, e.g. C. edule, in this study is consistent with other observations (e.g. Ysebaert et al., 2003), and is probably related to the low amount of phytoplankton in this region of the Schelde estuary and the high concentration of suspended solids, together with the high variation in salinity.

Several taxa, common in April and September (mainly smaller species like Oligochaeta, Nematodes and $M$. aestuarina), showed a shift from a dominant position in the upper layer of the sediment in April towards a more dominant distribution deeper in the sediment in September. One explanation might be a shift in feeding habits of these taxa, as is supported by a population study on Oligochaeta at the GBR station in the same period (Seys et al., 1999a). The latter observed a shift in species composition from a dominance of the Naididae Paranais litoralis and Amphichaeta sannio, two small, typically surface diatom feeding oligochaete species, in spring, to a dominance of the larger tubificids Heterochaeta costata and Tubificoides heterochaetus, two typically sub-surface 'head-down' deposit feeders in autumn.

In September the difference in occurrence and vertical distribution of the macrobenthic species reflected the different feeding guilds of the species. C. volutator is a typical surface deposit feeder that consumes large numbers of diatoms and bacteria, 
together with organic material and sediment particles (Gerdol \& Hughes, 1994b). C. volutator almost exclusively occurred in this study in the upper layer of the sediment, where highest chlorophyll $a$ contents were present. On the other hand, the polychaete $H$. filiformis occurred deeper in the sediment. H. filiformis is known as a typical subsurface deposit feeder, deriving all its food from sediment ingested in the anaerobic layer below the surface, depositing its faecal pellets at the surface (Cadée, 1979). M. balthica, mainly juveniles having a mean length of $3.45 \mathrm{~mm}(n=367)$, was situated in the top layer of the sediment. This is in accordance with several studies in which it was demonstrated that small Macoma lives at the top layer of the sediment with an increasing depth occurrence with size of the animal (Davey \& Partridge, 1998). The gastropod $H$. ulvae is a typical grazer, feeding mainly on benthic diatoms (Jensen \& Siegismund, 1980) and therefore found in the top layer of the sediment, as also demonstrated by this study. Like C. volutator, this species was significantly correlated with chlorophyll $a$ contents.

This study further indicated that both 500 and $250 \mu \mathrm{m}$ fractions where characterised by a high abundance of both meiobenthic and macrobenthic (in September) species. Especially in the low salinity zone of estuaries, it seems important to include these smaller fractions, as the benthic community is often populated here by very small species (e.g. M. aestuarina, Oligochaeta) or immature stages of larger species (e.g. C. volutator). It has been shown that for the study of estuarine Oligochaeta, these fractions are essential, since only a small part of the Oligochaeta occur in the $1000 \mu \mathrm{m}$ fraction (Seys et al., $1999 b)$. When studying population dynamics one should also include these smaller fractions of the benthos (e.g. C. volutator, Crewe et al., 2001).

\section{Acknowledgements}

This study was part of a hydraulic/morphological study of the Deurganck tidal dock, which has been carried out for the Ministry of the Flemish Community, Waterways and Marine Administration. We are grateful to Dr Helen Mitchener (HR Wallingford) for doing the measurements on the critical shear stress for erosion with the SEDEROD instrument. We are also grateful for the logistic assistance provided by the Maritime Scheldt division and for the bulk density analyses, which were carried out at Flanders Hydraulics. We thank Nico De Regge and Jan Soors for their assistance in the field and the laboratory. We are also grateful to Prof. M. Vincx and D. Van Gansbeke of the University of Ghent, Zoology Institute, Marine Biology Section for the analysis of the pigment contents. We thank Eric de Deckere and Peter Herman for comments on the manuscript. This study was partly supported by the FWO project G.0104.99. The Fund for Scientific Research is thanked for funding the Scientific Community 'Ecological characterization of European estuaries, with emphasis on the Schelde estuary' (Project nr. W 10/5 - CVW.D 13.816). This is contribution no. 3515 of the Netherlands Institute of Ecology (NIOO-KNAW).

\section{References}

Attrill, M. J., 2002. A testable linear model for diversity trends in estuaries. Journal of Animal Ecology 71: 262-269.

Barranguet, C., P. M. J. Herman \& J. J. Sinke, 1997. Microphytobenthos biomass and community composition studied by pigment biomarkers: importance and fate in the carbon cycle of a tidal flat. Journal of Sea Research 38: 59-70.

Bouma, H., P. P. de Vries, J. M. C. Duiker, P. M. J. Herman \& W. J. Wolff, 2001a. Migration of the bivalve Macoma balthica on a highly dynamic tidal flat in the Westerschelde estuary, The Netherlands. Marine Ecology Progress Series 224: 157-170.

Bouma, H., J. M. C. Duiker, P. P. de Vries, P. M. J. Herman \& W. J. Wolff, 2001b. Spatial pattern of early recruitment of Macoma balthica (L.) and Cerastoderma edule (L.) in relation to sediment dynamics on a highly dynamic intertidal sandflat. Journal of Sea Research 45: 79-93.

Brotas, V. \& M. R. Plante-Cuny, 1998. Spatial and temporal patterns of microphytobenthic taxa of estuarine tidal flats in the Tagus Estuary (Portugal) using pigment analysis by HPLC. Marine Ecology Progress Series 171: 43-57.

Cadée, G. C., 1979. Sediment reworking by the polychaete Heteromastus filiformis on a tidal flat in the Dutch Wadden Sea. Netherlands Journal of Sea Research 13: 441-456.

Crewe, T. L., D. J. Hamilton \& A. W. Diamond, 2001. Effects of mesh size on sieved samples of Corophium volutator. Estuarine, Coastal and Shelf Science 53: 151-154.

Davey, J. T. \& V. A. Partridge, 1998. The macrofaunal communities of the Skeffling muds (Humber estuary), with special reference to bioturbation. In Black, K. S., D. M. Paterson \& A. Cramp (eds), Sedimentary Processes in The Intertidal Zone. Special Publications, Geological Society, London, 139: 115-124. 
de Brouwer, J. F. C., S. Bjelic, E. M. G. T. de Deckere \& L. J. Stal, 2000. Interplay between biology and sedimentology in a mudflat (Biezelingse Ham, Westerschelde, The Netherlands). Continental Shelf Research 20: 1159-1177.

De Deckere, E. M. G. T., 2003. Faunal influence on sediment stability in intertidal mudflats. NIOO Thesis, 20. Ph.D. thesis, Rijksuniversiteit Groningen, Groningen, The Netherlands, $112 \mathrm{pp}$.

de Deckere, E. M. G. T., T. J. Tolhurst \& J. F. C. de Brouwer, 2001. Destabilisation of cohesive intertidal sediments by infauna. Estuarine, Coastal and Shelf Science 53: 665-669.

Defew, E. C., T. J. Tolhurst \& D. M. Paterson, 2002. Sitespecific features influence sediment stability of intertidal flats. Hydrology and Earth System Services 6: 971-982.

De Jong, D. J. \& V. N. De Jonge, 1995. Dynamics and distribution of microphytobenthic chlorophyll- $a$ in the Western Scheldt estuary (SW Netherlands). Hydrobiologia 31 1: 21-30.

Duplisea, D. E., 2000. Benthic organism biomass size-spectra in the Baltic Sea in relation to the sediment environment. Limnology and Oceanography 45: 558-568.

Fettweis, M. \& M. Sas, 1999. On the sedimentation of mud in access channels to the harbour of Antwerp. PIANC Bulletin 101: 53-59.

Fettweis, M., M. Sas \& J. Monbaliu, 1998. Seasonal, neapspring and tidal variation of cohesive sediment concentration in the Scheldt Estuary, Belgium. Estuarine, Coastal and Shelf Science 47: 21-36.

Gerdol, V. \& R. G. Hughes, 1994a. Effect of Corophium volutator on the abundance of benthic diatoms, bacteria and sediment stability in two estuaries in southeastern England. Marine Ecology Progress Series 114: 109-115.

Gerdol, V. \& R. G. Hughes, 1994b. Feeding behaviour and diet of Corophium volutator in an estuary in southeastern England. Marine Ecology Progress Series 114: 103-108.

Hagerthey, S. E., E. C. Defew \& D. M. Paterson, 2002. Influence of Corophium volutator and Hydrobia ulvae on intertidal benthic diatom assemblages under different nutrient and temperature regimes. Marine Ecology Progress Series 245: 47-59.

Hargrave, B. T., N. J. Prouse, G. A. Phillips \& P. A. Neame 1983. Primary production and respiration in pelagic and benthic communities at two intertidal sites in the upper Bay of Fundy. Canadian Journal of Fisheries and Aquatic Sciences 40 (Suppl. 1): 229-243.

Heip C. H. R., N. K. Goosen, P. M. J. Herman, J. Kromkamp, J. J. Middelburg \& K. Soetaert, 1995. Production and consumption of biological particles in temperate tidal estuaries. Oceanography and Marine Biology: An Annual Review: 1-149.

Herman, P. M. J., J. J. Middelburg, J. Van de Koppel \& C. H. R. Heip, 1999. Ecology of estuarine macrobenthos. Advances in Ecological Research 29: 195-240.

Herman, P. M. J., J. J. Middelburg, J. Widdows, C. H. Lucas \& C. H. R. Heip, 2000. Stable isotopes' as trophic tracers: combining field sampling and manipulative labelling of food resources for macrobenthos. Marine Ecology Progress Series 204: 79-92.

Herman, P. M. J., J. J. Middelburg \& C. H. R. Heip, 2001. Benthic community structure and sediment processes on an intertidal flat: results from the ECOFLAT project. Continental Shelf Research 21: 2055-2071.

Holland, A. F., A. T. Shaughnessy \& M. H. Hiegel, 1987. Long-term variation in mesohaline Chesapeake Bay macrobenthos: spatial and temporal patterns. Estuaries 10: 227-245.

Jensen, K. T. \& H. R. Siegismund, 1980. The importance of diatoms and bacteria in the diet of Hydrobia species. Ophelia (Suppl.) 17: 193-199.

Jongman, R. H. G., C. J. F. ter Braak \& O. F. R. Van Tongeren, 1987. Data Analysis in Community and Landscape Ecology. Pudoc, Wageningen.

Lucas, C. H. \& P. M. Holligan, 1999. Nature and ecological implications of algal pigments diversity on the Molenplaat tidal flat (Westerschelde estuary). Marine Ecology Progress Series 180: 51-64.

Luckenback, M. W. 1986. Sediment stability around animal tubes: the roles of hydrodynamic processes and biotic activity. Limnology and Oceanography 31: 779-787.

MacIntyre, H. L. \& J. J. Cullen, 1996. Primary production by suspended and benthic microalgae in a turbid estuary: time scales of variability in San Antonio bay, Texas. Marine Ecology Progress Series 122: 245-268.

Mantoura, R. F. C. \& C. A. Llewellyn, 1983. The rapid determination of algal chlorophyll and carotenoid pigments and their breakdown products in natural water by reverse phase high performance liquid chromatography. Analytica Chimica Acta 151: 297-314.

Meadows, P. S., J. Tait \& S. A. Hussain, 1990. Effects of estuarine infauna on sediment stability and particle sedimentation. Hydrobiologia 190: 263-266.

Middelburg, J. J., C. Barranguet, H. T. S. Boschker, P. M. J. Herman, T. Moens \& C. H. R. Heip, 2000. The fate of the intertidal microphytobenthos carbon: an in situ $13 \mathrm{C}$ labelling study. Limnology and Oceanography 45: 1224-1234.

Mitchener, H. J., R. J. S. Whitehouse, R. L. Soulsby \& V. A. Lawford, 1996. Estuarine Morphodynamics - Instrument Development for Mud Erosion Measurements. Development and testing of SedErode - Sediment Erosion Device. HR Report No. TR 16, HR Wallingford, Oxon, UK, October 1996.

Mouritsen, K. N., L. T. Mouritsen \& K. T. Jensen, 1998. Change of topography and sediment characteristics on an intertidal mudflat following mass-mortality of the amphipod Corophium volutator. Journal of the Marine Biological Association of the United Kingdom 78: 1167-1180.

Paterson, D. M. \& K. S. Black, 1999. Water flow, sediment dynamics and benthic ecology. Advances in Ecological Research 29: 155-193.

Paterson, D. M., K. H. Wiltshire, A. Miles, J. Blackburn, I. Davidson, M. G. Yates, S. McGrorty \& J. A. Eastwood, 1998. Microbiological mediation of spectral reflectance from intertidal cohesive sediments. Limnology and Oceanography 43: 1207-1221.

Saiz-Salinas, J. I. \& Q. Ramos, 1999. Biomass size-spectra of macrobenthic assemblages along water depth in Antarctica. Marine Ecology Progress Series 178: 221-227.

Santos, P. J. P., J. Castel \& L. P. Souza-Santos, 1996. Seasonal variability of meiofaunal abundance in the oligo-mesohaline 
area of the Gironde estuary, France. Estuarine, Coastal and Shelf Science 43: 549-563.

Seys, J., M. Vincx \& P. Meire, 1999a. Macrobenthos of the Zeeschelde, with special reference to the distribution and role of Oligochaeta. Report Institute of Nature Conservation 99.4 (in Dutch).

Seys, J., M. Vincx \& P. Meire, 1999b. Spatial distribution of oligochaetes (Clitellata) in the tidal freshwater and brackish parts of the Schelde estuary (Belgium). Hydrobiologia 406: $119-132$.

Snelgrove, P. V. R. \& C. A. Butman, 1994. Animal-sediment relationships revisited: cause versus effect. Oceanography Marine Biology Annual Review 32: 111-177.

Sokal, R. R. \& F. J. Rohlf, 1981. Biometry. Freeman, San Francisco, CA.

ter Braak, C. J. F., 1994. Canonical community ordination. Part I. Basic theory and linear methods. Ecoscience 1: 127-140.

ter Braak, C. J. F. \& P. Smilauer, 1998. CANOCO Reference Manual and User's Guide to Canoco for Windows: Software for Canonical Community Ordination (version 4). Microcomputer Power, Ithaca, New York, 352 pp.

Underwood, G. J. C. \& D. M. Paterson, 1993. Seasonal changes in diatom biomass, sediment stability and biogenic stabilization in the Severn Estuary. Journal of the Marine Biological Association of the United Kingdom 73: 871-887.

Wartel, S., M. Shan Chen \& P. Schotte, 1998. Sea Scheldt, Tidal dock West: Gamma densimetric, granulometric and radioisotope study. Report Royal Belgian Institute of Natural Sciences, 36 pp (in Dutch).

Widdows, J. \& M. Brinsley, 2002. Impact of biotic and abiotic processes on sediment dynamics and the consequences to the structure and functioning of the intertidal zone. Journal of Sea Research 48: 143-156.

Widdows, J., M. D. Brinsley, P. N. Salkeld \& C. H. Lucas, 2000. Influence of biota on spatial and temporal variation in sediment erodability and material flux on a tidal flat (Westerschelde, The Netherlands). Marine Ecology Progress Series 194: 23-37.

Wolff, W. J., 1983. Estuarine benthos. In B. H. Ketchum (ed.), Ecosystems of the World 26: Estuaries and Enclosed seas., Elsevier, Amsterdam; 151-183.

Yallop, M. L., B. De Winder, D. M. Paterson \& L. J. Stal, 1994. Comparative structure, primary production and biogenic stabilization of cohesive and non-cohesive marine sediments inhabited by microphytobenthos. Estuarine, Coastal and Shelf Science 39: 565-582.

Ysebaert, T. \& P. M. J. Herman, 2002. Spatial and temporal variation in benthic macrofauna and relationships with environmental variables in an estuarine, soft-sediment environment. Marine Ecology Progress Series 244: 105-124.

Ysebaert, T., P. Meire, D. Maes \& J. Buijs, 1993. The benthic macrofauna along the estuarine gradient of the Schelde estuary. Netherlands Journal of Aquatic Ecology 27: 327-341.

Ysebaert, T., P. Meire, J. Coosen \& K. Essink, 1998. Zonation of intertidal macrobenthos in the estuaries of Schelde and Ems. Aquatic Ecology 32: 53-71.

Ysebaert, T., P. M. J. Herman, P. Meire, J. Craeymeersch, H. Verbeek \& C. H. R. Heip, 2003. Large-scale spatial patterns in estuaries: estuarine macrobenthic communities in the Schelde estuary, NW-Europe. Estuarine, Coastal and Shelf Science 57: 335-355. 